\title{
2101 ハンドルハブの力学的試験用万能ジグの開発
}

Development of all-around Jig for endurance test of steering wheel hubs

$$
\text { ○正 小西 毅（都産技研）市川 泰章（㑣ワークスベル） }
$$

Takeshi KONISHI, Tokyo Metropolitan Industrial Technology Research Institute Azuma-cho 3-6-1 Akishima-shi Tokyo Yasuaki ICHIKAWA, Works Bell, Shimouma3-22-10 Setagaya-ku Tokyo

The steering wheel hub (called hub, hereafter) is a product that connects the steering wheel and the steering wheel shaft for the car. It has an important function to make it run in the direction where the car is intended. There are two fatigue test standards to test the hubs, one is JASO C713 for genuine products, and the other is the ASEA standard of NAPAC for aftermarket products.

The authors have developed a new jig system to do the fatigue test for the hubs. The new jig has specific feature enabling to be applied to any hubs. Moreover, it has self alignment mechanism so that the defined testing force is applied to the hub straightforwardly and properly.

Keywords : Car, Steering wheel hub, JASO C713, Complete safety design, Durability

\section{1.はじめに}

ハンドルハブ(国内全種類)は、自動車用ハンドルとハン ドルシャフトとを連結させる製品である。機能と特徴は、自 動車を意図する方向へ走行させるための重要な機能用品で あると同時に、ファッション用品としての役割ももっている がドライバーの安全に係わる大事な部品である。ハンドルハ ブに関しての団体規格としては、1983 年に自動車メーカのラ イン装着の試験規格として社団法人自動車技術会が出版し た自動車部品一ステアリングホイールの試験方法 (JASO C 713） ${ }^{(1)}$ が制定されている。この試験規格の項目に耐久試験が ある。一方でアフターマーケット製品用に考案された試験規 格として NAPAC（日本自動車用品・部品アフターマーケッ 卜振與会) (2)の ASEA 基準がある。ASEA 基準は JASO C713 の耐久試験に準拠し、試験力・負荷回数などのパラメータを より明確に記載されている。

JASOC713 が規定している試験項目は、性能評価は静的強 度試験・耐久強度試験及び耐環境試験である。

本開発では静的曲げ試験・静的ねじり試験・曲げ耐久試 験・ねじり耐久試験を対象としている。

これらの対象規格に則って試験するには、都産技研本部で所 有する試験品に引張・圧縮力を加えることが可能な Fig.1 に 示す往復動耐久試験機（搳サム電子機械製 2-FV-05KN-BS)(以下、試験機)とハンドルハブに対応したジグ が必要となる。

ジグの準備に関して、現状では次の問題点があった。

(1)試験機に装着するために製品ごとに異なるジグを作る 必要がある。

(2)個別に作ったジグは規格どおりの力が加わらない構造 であった。

JASOC713 では、ジグの要件として「試験負荷以外が加わ らない構造とする」が求められている。

本開発では、任意のハブに取り付け可能な万能ジグで、規格
に適合した力を加えられるジグの開発を目指した。

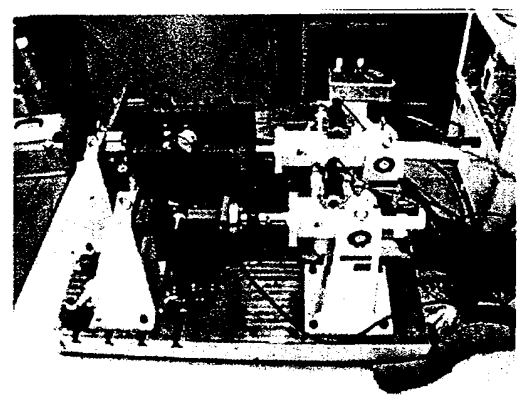

Fig.1 Endurance testing machine

\section{2. 開発ジグの概要}

Fig.2 は静的曲げ試験および曲げ耐久試験の概略図である。 静的曲汗試験は、1098N の負荷を与える。一方、曲げ耐久試 験は土221N の負荷を与える。Fig.3 は負荷静的対じり試験及 びねじり耐久試験の概略図である。静的㸚じり試験は、1098N の負荷を与える。一方、ねじり耐久試験は $\pm 221 \mathrm{~N}$ の負荷を与 える。
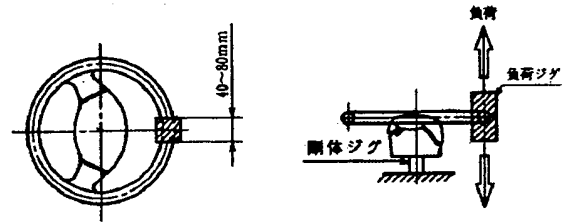

Fig. 2 Statically and Cyclically bending test model
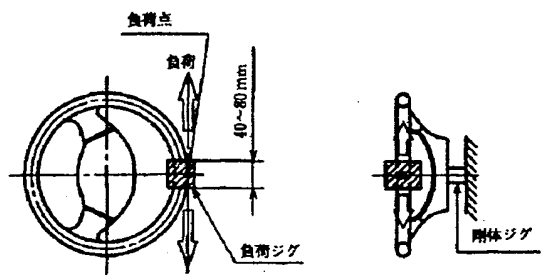

Fig.3 Statically and Cyclically torsion test model

〔№.10-54] 日本機械学会第 19 回交通・物流部門大会講演論文集 [2010-12.1～3. 川崎市] 
JASOC713 にある「試験負荷以外が加わらない構造」を検 討するにあたり、試験実施の際に想定される負荷を考える。 試験機は直線方向のみに試験品に負荷をあたえる。したがっ て、負荷を与えられた試験品にはひずみが生じ、直線方向の 負荷は徐々に分力となる。Fig.4 は試験品に対する系と負荷で ある。

周期的な力 $\mathrm{F}$ を与えることにより、モーメント $\mathrm{M}$ と張力

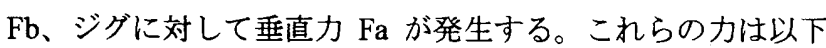
の式で示される(3)。

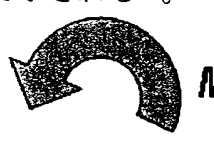

$M$

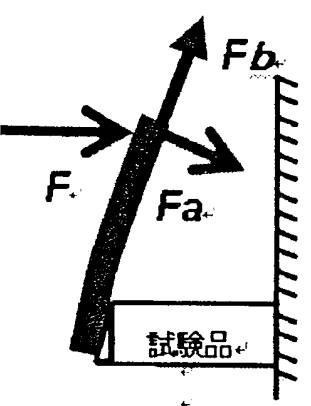

$$
\begin{aligned}
& F=A \sin \omega t \quad \text { より } \\
& F a=A \sin \omega t \cos \left(\frac{l^{2} A \sin \omega t}{2 E I}\right) \\
& F b=A \sin \omega t \sin \left(\frac{l^{2} A \sin \omega t}{2 E I}\right) \\
& M=l A \sin \omega t
\end{aligned}
$$

$\mathrm{A}$ : 最大試験力 $\omega$ : 角周波数

$\mathrm{E}:$ ヤング率

$\mathrm{I}$ : 断面 2 次モーメント

$1:$ 支点から作用点までの距離 $\mathrm{T}:$ 時間

Fig.4 Cantilever arm of loaded model

これらのカの中で試験品への負荷として Fa のみが必要であ り、それ以外の力は余剩力となる。 Fa を所定の負荷とするた めには、ハリに対し力を加えても常に垂直に力が加わる構造 を実現しなければならない。また、動作変位において荷重側 に動く機構を設計する必要がある。

Fig.5 は開発したジグを試験機に搭載したときを示してい る。試験ジグ全体の特徵としては、試験機のシリンダーの動 きに追従し、旋回テーブルが旋回する。旋回する向きは、ア 一ムに対し法線方向に負荷を与える向きに旋回する。これに より試験負荷以外の力が加わらない機構が実現した。

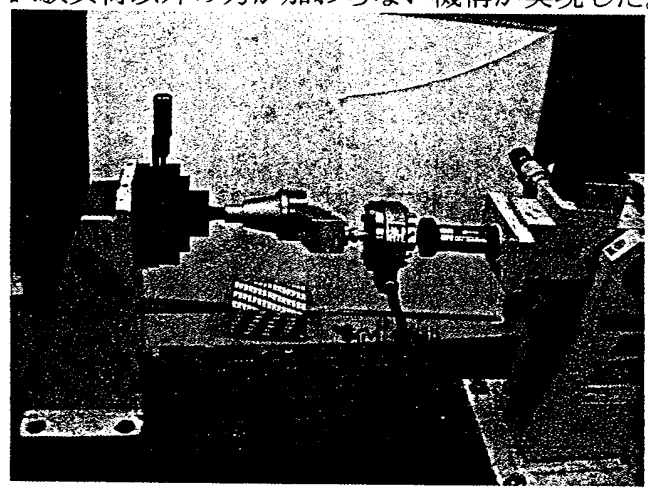

Fig. 5 Development Jig on Endurance testing machine

3. 開発ジグによる耐久性評価

開発したジグを試験機に装備し、ハンドルハブの耐久性評 価を行った。試験条件はJASO C 713 に規程される曲げ耐久 試験及びねじり耐久試験を行った。試験条件は以下の通りで ある。

- 周波数 : $1 \mathrm{~Hz}$

- 制御方式 : 力制御
- 最大負荷 : $\pm 221 \mathrm{~N}$

・動作パターン：正弦波
- 目標回数 : 10 万回

当試験でロードセルから得られたデータは、Fig.6及びFig.7 である。Fig.6 は曲げ耐久試験の初期サイクルにおけるロード セルからの応答の図である。応答は正弦波である必要がある ため正弦波との相関を求めた。相関は 0.9 であった。Fig.7は ねじり試験の初期サイクルにおけるロードセルからの忘答 の図である。応答は正弦波である必要があるため正弦波との 相関を求めた。相関は 0.9 であった。

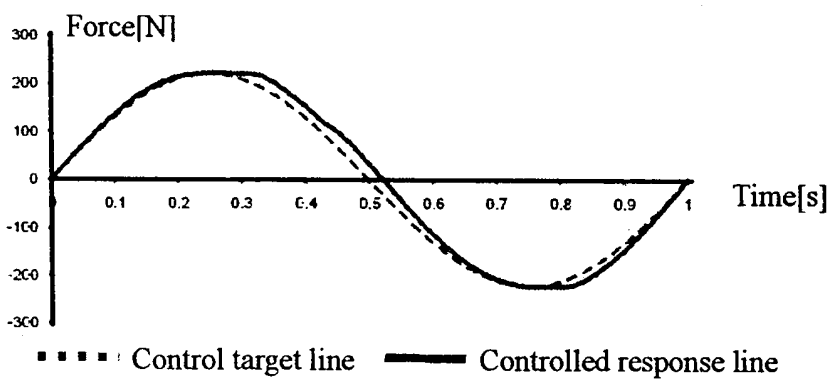

Fig.6 Cyclically bending test result

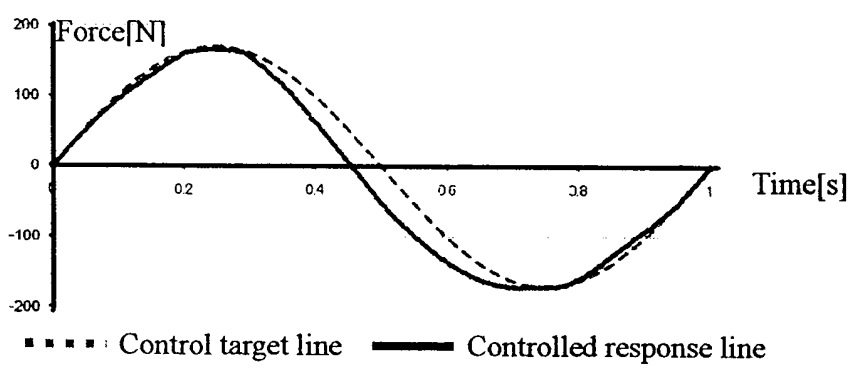

Fig.7. Statically bending test result

結果として曲げ耐久試験及びねじり耐久試験については、 試験前後の制御用ロードセルからは異なる值が示された。

初期サイクルと 10 万サイクル目の值を比較した。初期サ イクルと 10 万サイクル目の相関は 0.7〜0.9 以内であった。 ハンドルハブに対して主な破損や亀裂などはないと判断で きる。

4. まとめ

ハンドルハブの試験に必要な万能ジグを開発した。考案し た試験機のジグは、JASO の試験力以外に余分な力が加わら ない構造とするという規定を解決した。また、ハンドルハブ の耐久試験も行い、ハンドルハブに異常がないことを確認し た。

本開発で作製したジグの仕様及び性能を平成 22 年 3 月 24 日にNAPAC の技術委員会へ報告し、NAPAC から当センター が ASEA 基準認定のための指定試験機関として認定された。

\section{文献}

(1)社団法人自動車技術会 規格会議蕃議：「JASO C 713(2008), 社団法 人 自動車技術会 pp.4 12

(2)NAPAC : http://www.napac.jp/

(3)宮本 博,菊池正紀：「材料力学」，裳華房, pp.72 83 